\title{
An Analysis on The Devil Wears Prada from the Perspective of New Feminism
}

\author{
Liu Yan
}

Canvard College, Beijing Technology and Business University, No. 1 Song Zhuang Nan Lu,
Tong Zhou Dist, Beijing, China

liuyan_662003@163.com

Keywords: The Devil Wears Prada, The New Feminism, Career, Love.

\begin{abstract}
Movie is a creative art form under the society development which combines the politics, economy and culture. It shows the human psychological status and the ideology in an exaggerated way within several hours. It reflects richly on the changes of humanity and the psychology. In the movie The Devil Wears Prada, the protagonists make the different choices between the career and love, which demonstrates the expressions and features in the New Feminism. New Feminism is a term which is used to describe a range of viewpoints reacting to Feminism since the 1970s, and it updates the social status of women even the human beings. It focuses more on finding the harmony and integration between all the people and objects, as well, finds the fundamental liberation of women both from the materials and the soul. It infiltrates the self-transcendence of women into every field.This paper will explain the New Feminism by using the examples in the movie to show its influences on the society. Hopefully it is a reference and instruction for the female to make wise choices when meeting the dilemma of career and love.
\end{abstract}

\section{Introduction}

Movie is more like a magnifier of daily life. It influences people in many aspects, such as fashion, life style, career choosing even the attitude of life. The visual basis of movie gives us a universal power of communication.

\subsection{Introduction of The Devil Wears Prada}

The Devil Wears Prada is a 2006 comedy-drama film, a screen adaptation of Lauren Weisberger's 2003 novel of the same name. It is produced by Wendy Finerman and directed by David Frankel. It stars Anne Hathaway as Andrea Sachs, a naive just-graduated in journalism who goes to New York City and gets a job as a co-assistant to the ruthless and merciless executive of the Runway fashion magazine, Miranda Priestly, played by Meryl Streep. If she does as an outstanding co-assistant, she can be a member of the magazine and work with many luxury brand designers. But her biggest obstacle is to be accredited by the chief editor-Miranda, her boss. Miranda's fashion style and elegant manners make her be a point during the people. But she is very harsh to the employee and every employee thinks that she is a devil. Firstly, Miranda is mad at Andy's bad taste of the clothes and very strict to Andy. Every command is said once only and without one second delay. Andy also has to solve the unexpected events which are commanded by the boss. However, with the help of art director Nigel, she gradually learns her responsibilities and begins to dress more stylishly. She also meets the fancy young writer Christian Thompson, who offers to help her with her career. Andy changes her mind when all the work goes on track. She really does a good job in the company and knows lots of famous people. She becomes the first co-assistant. But another trouble comes, Andy has a contradiction with her boyfriend and friends who deem that Andy is more and more strange to them and Miranda is full of Andy's life instead of them. In the end, Andrea learns that life is made of choices. She chooses love and friendship. After that, she leaves the Runway and finds a new job to begin her new life!

\subsection{The Theory of the New Feminism}

The Oxford English Dictionary has pointed out that: "A feminist is 'an advocate or supporter of the 
rights and equality of women'". Feminist theory, which emerged as early as 1792 from these Feminist movements, includes anthropology, sociology, economics women's studies, literary criticism, art history, psychoanalysis and philosophy. Gilligan has said: "It aims to understand the nature of gender inequality by examining women's social roles and lived experience; it has developed theories in a variety of disciplines in order to respond to issues such as the social construction of sex and gender." [1]

New Feminism was originally used in Britain in the 1920s to distinguish New Feminists from traditional mainstream suffragist Feminism. The main characteristics are very practical instead of theoretical, almost non-ideological. It is a label for a wide range of theories that take critical approaches to previous feminist discourses and includes challenges to the early ideas. The term has been revived by feminists responding to the Vatican's call for a " 'new feminism' which rejects the temptation of imitating models of 'male domination' in order to acknowledge and affirm the true genius of women in every aspect of the life of society and overcome all discrimination, violence and exploitation." [2]

New Feminism breaks the limitation of the Old Feminism, and it does believe that male and female are different in essence, but they not only care about the liberation of the women, the equality of the both sexes but also the freedom of female, the harmonious development of the both sexes even the equality of nations and races and the liberation of nature. It often focuses on "micro-politics" and challenge the early paradigm as to what is, or is not, good for women, and tend to use a post-structuralist interpretation of gender and sexuality.

\section{Reflections of the New Feminism on Two Leading Heroines}

Simone de Beauvoir once said: "One is not born, but rather becomes, a woman." [3] This movie constructs the new images with strong self-consciousness that modern females subvert tradition through different angles, asserting a new value orientation that women can rely on themselves to realize the independence, equal rights and free marriage. It tells a story about finding and losing, missing and getting. By showing the different experiences of two leading heroines about career, marriage and love, it has set up a New Feminism model with more humanity, kindness, senses, stableness and maturity.

\subsection{Miranda Priestly}

In this movie, as the most typical role, Miranda shows us a "new woman" who think the career is the most important thing for them.

As for the career, she controls and even can makes waves in the fashion world. The success of her career highly appreciates the self value of women. When we look through the whole movie, you must be shocked and impressed by her ability on work. We can see that everyone in the office is afraid of Miranda. Because of her one action, the designer has to change all the things. She is the queen of the fashion world with absolute power. No one can defeat and replace her. She has fully interpreted the New Feminism that women can do everything.

As for love, both male and female have the weakness which is proposed by the New Feminism, they advocates that this is a time when we are aware of the limitations of human beings. Compared to the blindly pursuing the equality, to admit and accept sex differences is more conducive to the women's liberation.[4] So does Miranda, who has the vulnerable sides. She has many ideas about her marriage, family and life which cannot be spoken out. She is up to her best effort to satisfy her twin daughters' wishes no matter how unreasonable the wishes are. She really need someone to take care of her essentially, which is exposed completely when facing the sixth divorce, even though she tries to keep her family situation as a secret. That is the human.

\subsection{Andy Sachs}

In terms of women's liberation goals, the New Feminism aims at harmonious coexistence between male and female. Andy is another type of the New Feminism who chooses love as the most indispensable thing in life. She chooses to be honest to her heart. 
As for the career, she just looks like most of us today, who has a nice education background and do best to strive for the dreams. She is outgoing and full of passion. Certainly, she never gives up easily. At first, she is looked down by colleagues of her old-fashioned taste. By the help of the art director Nigel and her own hard-working, colleagues change their mind of her and Miranda begins to have trust in her. Finally, she becomes the first co-assistant and she is familiar to people in fashion world. When she realizes that there is a dilemma and conflict between her career and her associates, Andy finally chooses her lover and friends instead of the higher position. She gives up the work in the Runway, meets Nate again and reconciles with him. She finally becomes a member of the newspaper office, which she feels content with, too.

As for love, she has a boyfriend Nate who loves her very much and several friends who do take care of her. She knows that she has some weak points but she never gives up and always tries to improve herself. Because of Andy's hard work, there is a big gap between Andy and her boyfriend. They argue about it for many times. Finally, Nate breaks up with Andy. She feels awful but the job has to be continued. In Pairs, when Andy saw the weakness of the powerful woman Miranda for the first time after she is divorcing with her sixth husband, Andy just understands what she wants the most. The role of Andy fully stands for the female today under the New Feminism who care more about themselves than before when they found something which is good for them, then they would endeavor to get it.

\section{Conclusion}

Miranda is beautiful and graceful. Her tenacity, intelligence, her consistent tone of voice, as well as her love of career and persistence, for years, which make the people who have contact with her couldn't help but feeling so overawed and dwarfed that they cannot match up with her. In the midst grudge and curse, Miranda is leading a lively and colorful life.

Andy's generosity, kindness, tenacity, boldness, simplicity and openness have conquered us, which are more powerful than her dazzling beauty. She is just a common woman too, who has weakness, inner struggle and fighting when facing the choices. During her growth, there is retreat, vanity and material attraction, all of which are undeniable. She is easy, closed and more human.

A famous quote from Thomas Jefferson, the founding father of the United States, once said:"Give me liberty or give me death!" The struggle for freedom and equality is god's most precious gift to mankind. New Feminist do believe that they can help others, society even the country like male. What they desire is not to find a stable job, marry Mr. Right or are accepted by the main trend, but to have a deep thinking to understand the world, to recognize themselves and be faithful to their hearts. New Feminism positively expresses its proposition on human and non-human relations about various issues, and spare no effort to promote women's values to all of humanity, which provides a new vision on human freedom and development.

\section{References}

[1] Gilligan, Carol. In a Different Voice: Women's Conceptions of Self and Morality [N]. Harvard Educational Review. 1977, 47 (4), p. 418- 517

[2] Information on https://en.wikipedia.org/wiki/New_feminism

[3] Simone de Beauvoir. The Second Sex [M].New York: Bantam, 1952, p. 249

[4] Yang Feng. The Value and Theoretical Dilemma of New-feminism [J].Academic Forum. Guang Xi. 2009(4), p. 87 